\title{
NEW GENERATION OF REGIONAL UNIVERSITIES IN RUSSIA
}

\author{
Nataliia Ovchinnikova*1 Oksana Ovchinnikova ${ }^{2}$ Tatiana Kolmykova ${ }^{3}$ Vladimir Bredikhin ${ }^{3}$ \\ ${ }^{1}$ Moscow school of management SKOLKOVO, Russia \\ ${ }^{2}$ Voronezh State University, Voronezh, Russia \\ ${ }^{3}$ Southwest State University, Kursk, Russia
}

The regionalization of economic processes associated with digital transformation actualized the issue of the universities influence on the territories industrial development. The Russian industry has a significant gap from the industries of the developed countries, which raised the issue of the necessity the introduction of new technologies, new knowledge and the transformation of the traditional industry. The process of supporting the leading regional universities began in Russia with the aim of activating their interaction with the region's industry. The article analyzes the socio-economic situation of the regions, in which flagship universities receive state support. The main objective of such universities is the university-industry cooperation in the sphere of new knowledge and technologies. The authors analyzed socio-economic factors that encouraged regional universities to participate in the flagship universities project competitive selection. The article examines the first eleven universities that have become flagship in this project. The authors presented a regional university -industry cooperation business model. The article focuses on two forms of such cooperation: direct cooperation and triangle cooperation (university-industry-state). The article shows that the flagship universities project has positive results of implementation during the first years of realization. More than $70 \%$ of the flagship universities became active partners with the regional industry and pushed the growth of the regional economy. Moreover, this article puts a start to a large research about the university-industry cooperation, especially in the engineering universities. The main problems and barriers of university-industry cooperation in Russia are determined in the article.

Key words: Universities, Higher education, Technological innovation, University- industry cooperation, Incubators, Innovations

\section{INTRODUCTION}

The current Russian economic situation has undergone dramatic economic changes, with the sanctions, growing unemployment and great technological gap from the developed countries. Despite all developments which the Russian government have tried since 2013, the majority of them haven't worked. As European Parliament in 2015 said, the main problem of Russian industry development was the lack of diversity and new technologies in it. [06] We can mention some trends in the Russian industry such as:

- the lack of prerequisites for improving the investment climate;

- traditional industry has been transforming under the pressure of new technology progress;

- the lack of prerequisites for improving the geopolitical situation;

- the lack of prerequisites for the prices growth for oil and gas in the next 20 years.

After the identification of these problems The Ministry of Education and Science of the Russian Federation made a decision to invest in higher education system and pushing the economic growth with the help of university-industry cooperation. Simultaneously, Russian government is supporting innovation and R\&D projects.
In 2015 the ex-Minister of Education and Science of the Russian Federation Dmitry Livanov announced the second stage of the higher education reform in Russia: the creation of a network of new generation of regional universities. The program will be lasting till the end of 2020 year when the first "wave" of flagship universities will show the results of their work. Two basic theses are based on the creation of flagship higher education institutions: the absolute reduction in the number of students due to the demographic failure and the consolidation of higher education in the regions in order to improve the quality of the educational services provided. Despite all this purposes the main active for universities became a university-industry cooperation. [07]

Nowadays, we face with the fact that our universities have a wall of misunderstanding which leads to distraction of university-industry cooperation, such as:

- R\&D projects of universities mostly don't meet the needs of the real sector;

- the activity of developers and subjects of innovation infrastructure of universities is often only formally aimed at the commercialization of innovations, and in fact only for writing reports;

- the algorithm of the commercialization process is absent, because the existing subjects of the innovation infrastructure are weakly interconnected; 
- there is no effective system of motivation and stimulation of researchers in commercialization R\&D projects;

- the entrepreneurial spirit in universities is not sufficiently developed. (A.I. Sukhinov, E. A. Ugnich, 2017)

\section{FLAGSHIP UNIVERSITIES LOCATION}

In 201511 universities were chosen from 11 regions for their future development. More than a half of this universities are in regions were ones of the most depressed (Chart 1 and Chart 2). But in the competitive selection of the flagship universities, not only depressed regions have participated, but also strong regions that want to improve the level of education. [04]

As we can see, there were a big variety of different population volume cities from small like Kostroma and Oryol to large like Omsk, Samara. Seven cities out of eleven exceed the bar in a million people and four of them are small cities.[04] The presented statistical data makes it possible understand the scale of the implemented proj- ect and its need for the development of the social and economic situation of the Russian regions. Urban population mostly consists of rural population which changed their place of living and became citizens. [06]

On the Chart 3 we can identify that only few cities have positive migration balance. The majority of them have negative migration balance because of the unemployment, low wages and bad socio-economic situation. Universities in these cities faced with the problems which they can solve only with the help of cooperation between universities and industry. This will work because industry uses old technology and didn't modernize them and universities can help them in this field. [08]

Continuing the description of cities of flagship universities, we analyze the age groups of these cities (Chart 4) [23].

Chart shows that there are a lot of people of retirement age. This situation can lead to the growth of load to the young and employed population. In the case of unemployment and low wages, new generation of poverty will be produced. [24]

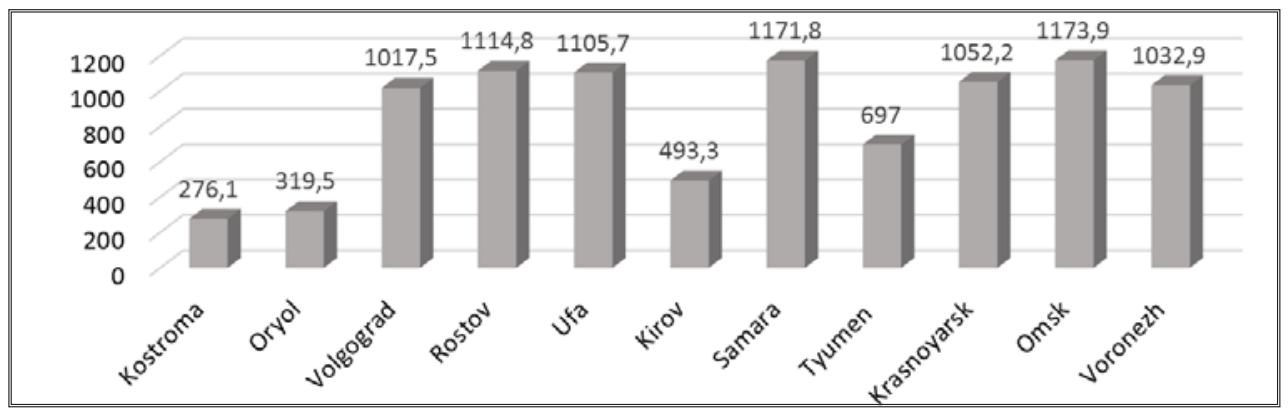

Chart 1: The Russian Federation regions population (cities of flagship universities location), thousands

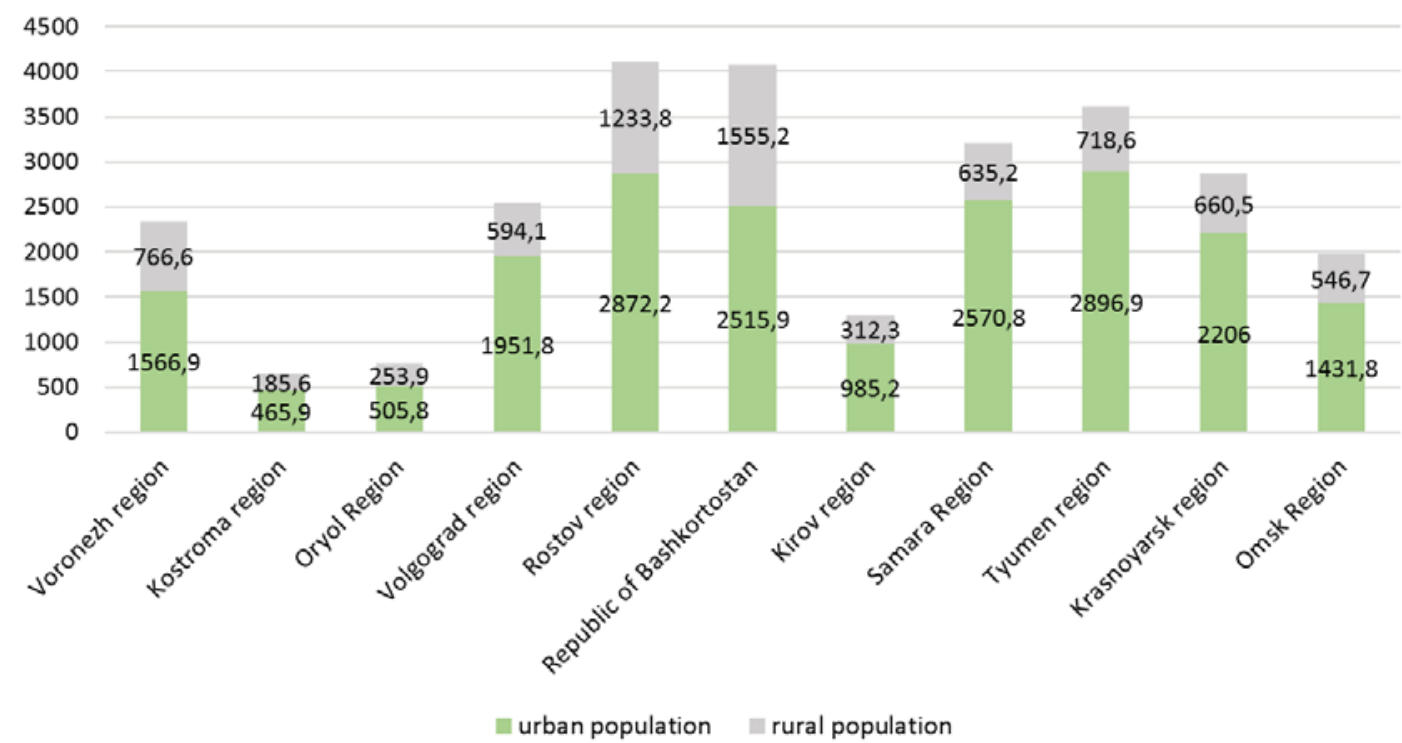

Chart 2: The Russian Federation regions population by categories (cities of flagship universities location), thousands 


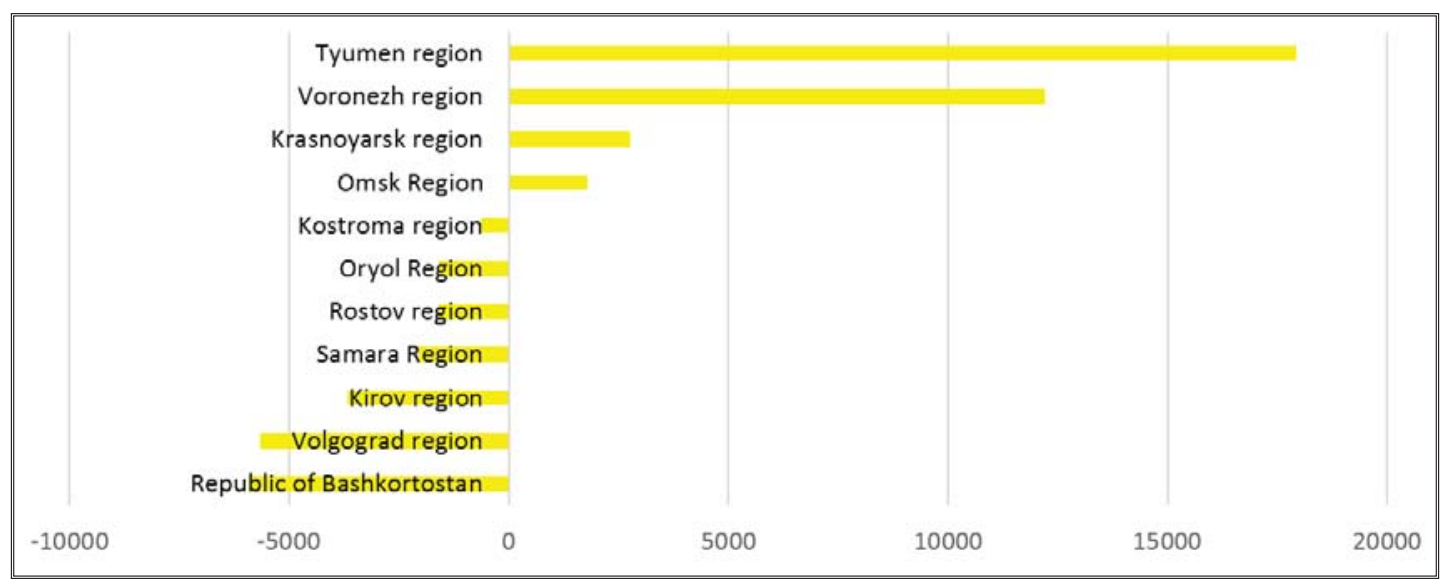

Chart 3: Migration flows

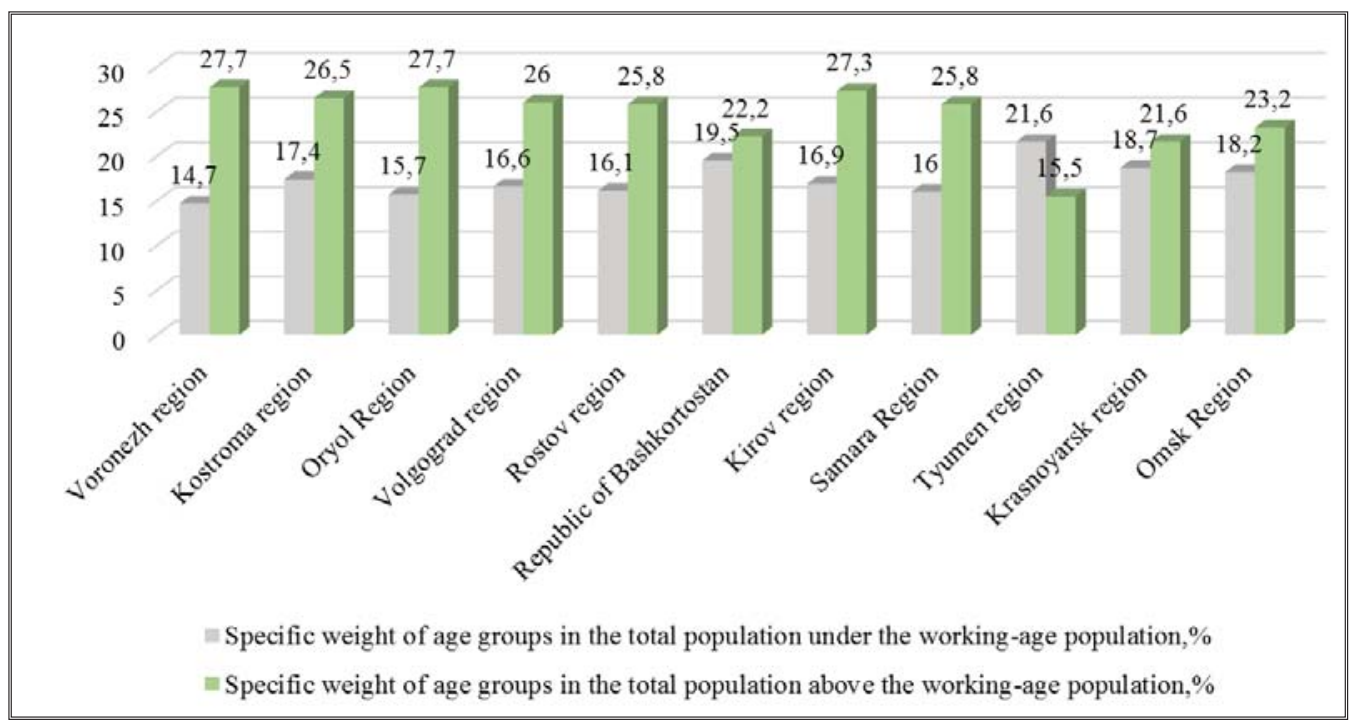

Chart 4: Percentage of different age groups in the total population

Analyzing the above indicators, it is possible to supplement them with regional ratings according to the version of the rating agency RIA on the quality of living (Table 1) [22] and socio-economic situation (Table 2) [26].

As for the quality of living, most of the regions are in low positions, which indicates the need for structural changes and the establishment of a new policy in the regions, in which the university will be the main actor.

Analyzing Table 2, we identify that the regions surrendered their positions on the socio- economic situation, which negatively affects the attractiveness of the region, both for the population, and for enterprises and businesses.

One of the important indicators for assessing the economic situation of the region is the estimation of the population incomes. [05] Table 3 presents the results of statistical data on average per capita population income through the years. [27]
From the data above, we note that the average per capita population income in the presented regions is 384,44 euro. The living minimum wage in Russia for 2016 by the Ministry of Finance is set at a rate from 111,43 to 288,57 euro depending on the city. The data presented indicate that people in the regions live below the poverty line. To solve this problem, it is necessary to create flagship universities and develop university-industry cooperation. Important aspects in the analysis of the income of the population are the consideration of income sources and promising industries, where people prefer to earn money. 
Table 1: Place in the rating of the Russian regions on quality of living for 2013 -2016 years (the end of the year results) [22]

\begin{tabular}{|c|c|c|c|c|}
\hline Region & 2013 & 2014 & 2015 & 2016 \\
\hline Voronezh region & 9 & 7 & 8 & 7 \\
\hline Tyumen region & 8 & 8 & 11 & 10 \\
\hline Samara Region & 14 & 13 & 13 & 16 \\
\hline Rostov region & 16 & 16 & 18 & 18 \\
\hline $\begin{array}{c}\text { Republic } \\
\text { of Bashkortostan }\end{array}$ & 20 & 19 & 21 & 25 \\
\hline Omsk Region & 23 & 26 & 37 & 52 \\
\hline Volgograd region & 29 & 37 & 31 & 40 \\
\hline $\begin{array}{c}\text { Krasnoyarsk } \\
\text { region }\end{array}$ & 47 & 47 & 43 & 43 \\
\hline Kostroma region & 52 & 48 & 53 & 54 \\
\hline Oryol Region & 57 & 54 & 44 & 35 \\
\hline Kirov region & 54 & 55 & 56 & 60 \\
\hline
\end{tabular}

Table 2: Place in the rating of the Russian regions on the socio-economic situation for 2013-2015 years (the end of the year results)[09]

\begin{tabular}{|c|c|c|c|}
\hline Region & 2013 & 2014 & 2015 \\
\hline Tyumen region & 8 & 7 & 8 \\
\hline Samara Region & 6 & 9 & 13 \\
\hline $\begin{array}{c}\text { Republic } \\
\text { of Bashkortostan }\end{array}$ & 10 & 10 & 10 \\
\hline Krasnoyarsk region & 15 & 16 & 14 \\
\hline Rostov region & 17 & 22 & 24 \\
\hline Voronezh region & 20 & 24 & 19 \\
\hline Omsk Region & 25 & 25 & 28 \\
\hline Volgograd region & 38 & 36 & 34 \\
\hline Kirov region & 54 & 52 & 48 \\
\hline Oryol Region & 60 & 62 & 63 \\
\hline Kostroma region & 63 & 71 & 75 \\
\hline
\end{tabular}

Table 3 - Average per capita population income [02]

\begin{tabular}{|c|c|c|c|c|c|}
\hline \multirow{2}{*}{ Region } & \multicolumn{3}{|c|}{$\begin{array}{c}\text { Average per capita population } \\
\text { income }\end{array}$} & $\begin{array}{c}\text { The place occupied } \\
\text { region in the Russian } \\
\text { Federation out of 84 } \\
\text { in 2016 year [25] }\end{array}$ \\
\cline { 2 - 5 } & 2012 & 2013 & 2014 & 2015 & 22 \\
\hline Voronezh region & 270,69 & 478,19 & 364,36 & 431,29 & 66 \\
\hline Volgograd region & 228,73 & 251,29 & 272,23 & 310,34 & 62 \\
\hline Kirov region & 239,04 & 257,31 & 290,41 & 316,71 & 64 \\
\hline Kostroma region & 226,67 & 251,07 & 276,00 & 320,94 & 30 \\
\hline Krasnoyarsk region & 321,77 & 356,03 & 354,37 & 387,47 & 37 \\
\hline Omsk Region & 278,50 & 305,20 & 343,71 & 369,40 & 57 \\
\hline Oryol Region & 240,39 & 260,89 & 285,44 & 326,29 & 26 \\
\hline $\begin{array}{c}\text { Republic } \\
\text { of Bashkortostan }\end{array}$ & 303,81 & 341,31 & 371,01 & 396,34 & 33 \\
\hline Rostov region & 258,67 & 299,93 & 371,01 & 379,23 & 29 \\
\hline Samara Region & 352,80 & 383,79 & 372,31 & 396,17 & 7 \\
\hline Tyumen region & 478,19 & 353,30 & 378,70 & 594,64 & \\
\hline
\end{tabular}

${ }^{1}$ Exchange course 1 Euro $=70$ Rub

The next stage in considering the feasibility of establishing flagship universities is the analysis of the socio-economic situation, including indices of industrial production, agricultural production, construction, retail trade turnover, paid services to the population, investments in fixed assets, consumer prices. Included indicators characterize the financial performance of organizations, arrears in wages, cash income of the population, as well as data on the structure of employment and its dynamics. Particular attention should be paid to the liquidation / foundation of organizations per 1000 organizations, which has a real reflection of the regional economics (Table 4)[21].

The coefficient of official liquidation / of organizations is the ratio of the number of officially liquidated organizations over the reporting period to the average number of organizations recorded in the Statistical Register by state statistics bodies based on state registration data in the reporting period, calculated for 1000 organizations. 
Table 4: Factor of liquidation / foundation of organizations per 1000 organizations $^{2}$

\begin{tabular}{|c|c|c|c|c|c|c|}
\hline \multirow{2}{*}{ Region } & \multicolumn{3}{|c|}{$\begin{array}{c}\text { Indicators of liquidation of } \\
\text { organizations }\end{array}$} & \multicolumn{3}{c|}{$\begin{array}{c}\text { Indicators of foundation of } \\
\text { organizations }\end{array}$} \\
\cline { 2 - 7 } & 2013 & 2014 & 2015 & 2013 & 2014 & 2015 \\
\hline Voronezh region & 51,8 & 70,3 & 99,1 & 98,2 & 111,3 & 135,4 \\
\hline Kostroma region & 60,5 & 93,4 & 58,9 & 72,6 & 77,9 & 75,8 \\
\hline Oryol Region & 48,5 & 57,5 & 41,5 & 79,8 & 68,8 & 74,0 \\
\hline Volgograd region & 62,2 & 59,6 & 63,0 & 98,5 & 87,4 & 83,0 \\
\hline Rostov region & 67,9 & 57,7 & 45,7 & 82,9 & 78,9 & 81,4 \\
\hline Republic of Bashkortostan & 58,2 & 103,9 & 75,4 & 97,1 & 88,4 & 93,3 \\
\hline Kirov region & 61,2 & 71,7 & 62,2 & 104,4 & 99,3 & 86,1 \\
\hline Samara Region & 74,6 & 74,8 & 93,3 & 114,7 & 106,2 & 116,5 \\
\hline Tyumen region & 70,6 & 90,7 & 50,9 & 115,8 & 108,0 & 100,7 \\
\hline Krasnoyarsk region & 64,2 & 64,2 & 64,2 & 118,7 & 101,6 & 99,3 \\
\hline Omsk Region & 67,7 & 86,8 & 60,4 & 96,2 & 93,1 & 104,9 \\
\hline
\end{tabular}

${ }^{2}$ The coefficient of official liquidation / foundation of organizations is the ratio of the number of officially liquidated organizations over the reporting period to the average number of organizations recorded in the Statistical Register by state statistics bodies based on state registration data in the reporting period, calculated for 1000 organizations

The presented data shows that in the regions where the main universities will be established, the liquidation of organizations is growing (almost 2 times compared with the period of the financial crisis of 2008), which indicates the need for fundamental changes in the policy of the regions and change development coordinates. As for foundation of organizations, there is a decrease both in comparison with the previous year and with the level of 2008.

In order to choose a priority regional specialization of regions it is important to assess the structure of GDP by region. The regional universities will not be able to restructure the entire economic system, this is why it is necessary to focus on the regional specialization, form a development line and a pool of opportunities in this direction. [26]

After the analyze of statistics of importance of creating the flagship universities, government chose 11 universities. The program for the creation of flagship universities implies changes in the structure of universities and their new role in the regions. The purpose of this program is to create one flagship university in the region that will meet the requirements of modernity and be able to be competitive and attractive for industry to work with them. In addition, the flagship university is determined to become an intellectual city-forming enterprise.

The first and main moment in the process of implementing this program is the "creation" of the flagship university by merging existing universities in the region into one university, which will be the flagship one. It unites not only the assets of universities (buildings, sports complexes, etc.), but also budgets and human capital.
In addition, the flagship universities were being created with the goal of optimizing and increasing the effectiveness of budget financing for higher education. [08]

Furthermore, flagship universities haven't only additional funding, which is implicit in the program (100-150 million rubles per year), but also the basic higher educational institution receives budgetary funds from universities that became a part of the basic university (1-2 universities in the region were united as a minimum). Thus, this excluded illogical expenditure of budgetary funds and all resources types are concentrated.

\section{FLAGSHIP UNIVERSITIES - MAIN INDICATORS}

As we said earlier, 11 flagship universities won in the first competitive selection: «Industrial University of Tyumen» (IUT), «Kostroma State University» (KSU), «Reshetnev Siberian State University of Science and Technology» (SibSAU), Ufa State Petroleum Technological University (USPTU), "Voronezh State Technical University» (VSTU), Don State Technical University (DSTU), «Volgograd State Technical University» (VolSTU), «Samara State Technical University» (SSTU), "Omsk State Technical University »(OmSTU), "Orel State University named after I.S. Turgenev» (OSU), «Vyatka State University»( VyatSU). More detailed information presented in the Table 5.

The Moscow school of Management SKOLKOVO made a comparative table which presented the threshold requirements from the Ministry of Education and Science of the Russian Federation and the real situation in the flagship universities (Table 6). 


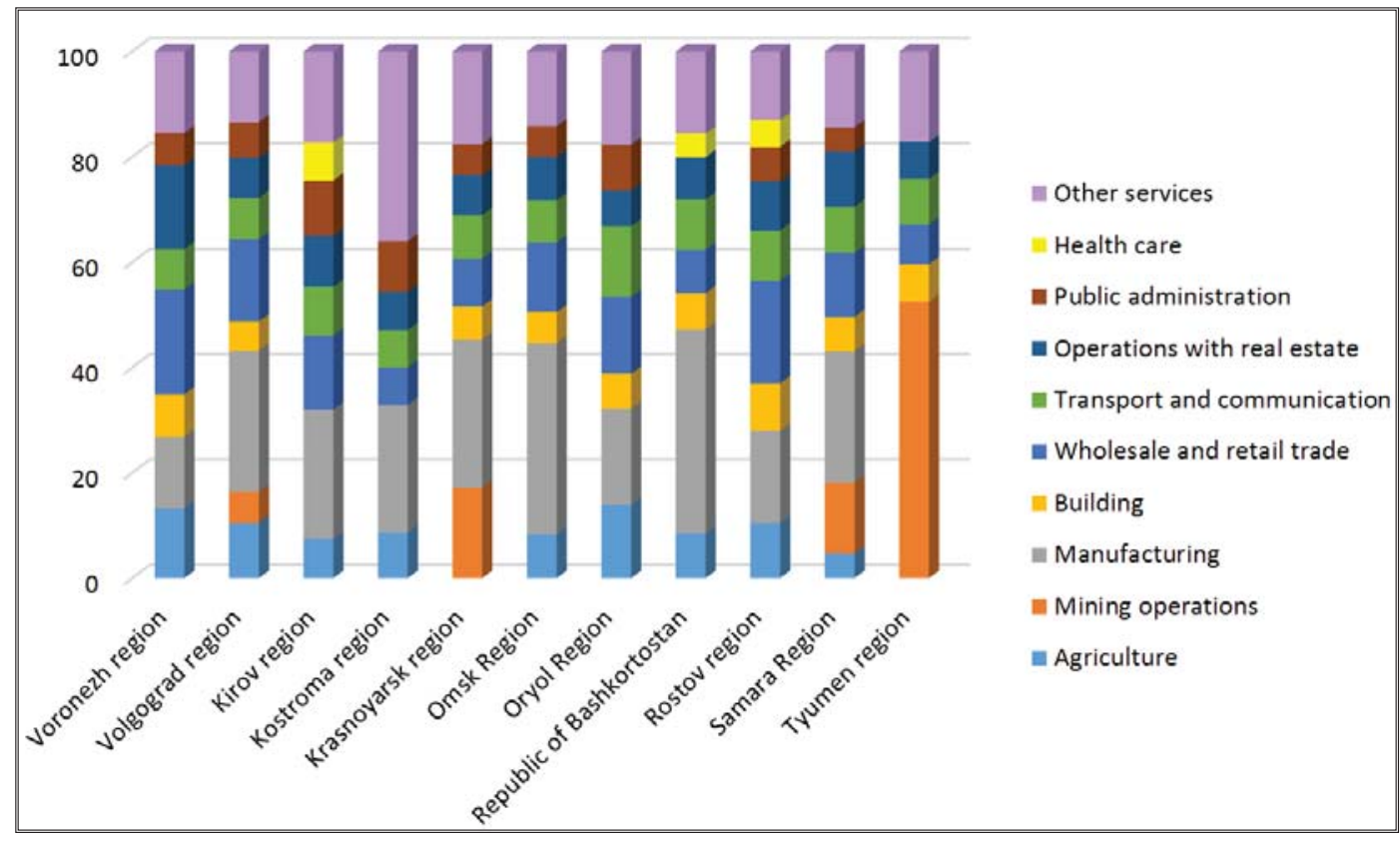

Chart 6: GDP structure by regions [27]

Table 5: Flagship universities data

\begin{tabular}{|c|c|c|c|c|}
\hline University & Established & Students & Academic staff & Faculties \\
\hline «IUT» [11] & 1956 & 11748 & 1012 & 45 \\
\hline «KSU» [12] & 1932 & 4211 & 388 & 28 \\
\hline «SibSAU» [16] & 1960 & 9200 & 1294 & 48 \\
\hline «USPTU» [17] & 1948 & 9565 & 1153 & 37 \\
\hline «VSTU» [19] & 1956 & 10600 & 1070 & 36 \\
\hline «DonSTU» [10] & 1930 & 16500 & 4712 & 85 \\
\hline «VolSTU» [18] & 1930 & 9200 & 1449 & 135 \\
\hline «SSTU» [15] & 1914 & 11089 & 1200 & 84 \\
\hline «OmSTU» [13] & 1942 & 9300 & 1115 & 44 \\
\hline «OSU» [14] & 1931 & 10200 & 992 & 87 \\
\hline «VyatSU» [20] & 1963 & 10800 & 1155 & 51 \\
\hline
\end{tabular}


The red zone shows backlog of indicators in the sphere of R\&D research, publications and the number of students. The decision was made, flagship university had to develop these spheres and tried to cooperate with the key industries in their regions. At the end of the 2015 year each flagship university followed the new business model of cooperation between university and industry [01].

It goes without saying that one of the main actors in this model is regional government. Mostly with the supporting from the regional government, university and industry can find each other. In the case of flagship universities, regional government plays a pivotal role because it helps universities become a main actor in regional development in different spheres including industry, business, corporations and others.

\section{UNIVERSITY-INDUSTRY COOPERATION}

In terms of university-industry cooperation flagship universities have two options: a direct cooperation and the triangle cooperation which is mentioned above.

Direct university-industry cooperation for flagship universities include:

- Small Innovative Enterprise,

- Specialized departments,

- Technology incubators,

- Start-ups,

- R\&D cooperation.

Over the last two years the majority of flagship universities made a stable connection with industry with the help of a direct cooperation. The role of regional government is decreasing from year to year. This trend is a foundation of not even possible model of economic growth. Before the sanctions many universities had target places for students. Its number fluctuated within the $5 \%$ of all students. The new model gives an opportunity to all students be a part of university industry cooperation. Table 7 shows the main ways of cooperation using by flagship universities. It is a complex analysis of the information which is given in the article of I. V. Arzhanova, A. B. Vorov, D. O. Derman, E. A. Dyachkova, A. V. Klyagin (2017) [03] and which are presented on the flagship universities web-sites.

Research has found that flagship universities have some difficulties with industry in the sphere of R\&D cooperation. This is explained by the following reasons:

- ineffectiveness or lack of technologies marketing and competencies, search of commercial customers;

- inactive search for solutions of using and commercialization R\&D;

- weak interaction between research and development units and units engaged in stimulating R\&D commercialization.
The best results are in the specialized departments foundation which are based on university-industry cooperation. These specialized departments have located in the enterprises. This position helps a student to study and practice new skills and competencies simultaneously.

The second one is foundation of a department which is the main purpose to help students to make start-ups. The foundation of this department has influence not only on university, but also on region. More than $20 \%$ of start-ups in each flagship university are successfully developed.

\section{DISCUSSION}

Taking everything into consideration, over the past two years the realization of the project "flagship university" shows great results. More than $70 \%$ of flagship universities became the active partners of regional industry and pushed increase of the regional economy. By means of flagship universities project regions with strong economy situation strengthen their positions and depressed regions started making first steps to economic well-being.

Besides all this positive effect we still have a lot of economic problems and need to develop this project. In the middle of 2017 year The Ministry of Education and Science of the Russian Federation made a decision to expand the project and announced a completion for the title «flagship university». The second wave of the project includes 22 «flagship university». The third wave of flagship universities is planned by The Ministry of Education and Science of the Russian Federation in 2018 year. This is really unique and successful project which have ever been realized in Russian Federation for small universities and industry simultaneously and had so fast results.

\section{IMPLICATIONS FOR THEORY, PRACTICE AND FUTURE RESEARCH}

This study shows the premises and background of flagship universities creation in Russian Federation. This project is lasting for two years and shows only the first small results. All we can see now is just the top of an iceberg. This study suggests the usefulness of continuing research on flagship universities-industry cooperation, as follows:

1. Identify the main patterns of university-industry cooperation including the second wave of flagship universities, especially engineering oriented flagship universities.

2. Building the model of the typical flagship universityindustry cooperation with a flexible part which can help other universities adopt this model for their educational ecosystem. 


\begin{tabular}{|c|c|c|c|c|c|c|c|c|c|c|}
\hline $\begin{array}{l}\stackrel{\supset}{0} \\
\stackrel{+}{\infty} \\
\stackrel{3}{>}\end{array}$ & $\begin{array}{l}8 \\
\infty \\
\circ\end{array}$ & 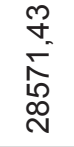 & প్ల & $\sigma$ & న్ & $m$ & م & ○ & ఉా & $\begin{array}{l}0 \\
0 \\
0\end{array}$ \\
\hline गे & $\begin{array}{l}\text { O } \\
\text { 음 }\end{array}$ & $\begin{array}{l}\text { m } \\
\stackrel{5}{5} \\
\stackrel{i}{\infty} \\
\stackrel{\infty}{N}\end{array}$ & ம & $\stackrel{\llcorner}{\llcorner}$ & R & $N$ & $\sim$ & 8 & $\Lambda$ & $N$ \\
\hline $\begin{array}{l}? \\
\frac{2}{0} \\
\stackrel{0}{9}\end{array}$ & 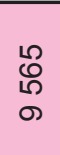 & 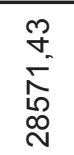 & $\approx$ & $\stackrel{\llcorner}{\llcorner}$ & 於 & م & 0 & in & $\wedge$ & $m$ \\
\hline$\frac{?}{\frac{20}{0}}$ & $\begin{array}{l}\text { ¿े } \\
\text { o }\end{array}$ & 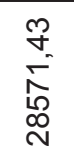 & $\hat{N}$ & $F$ & $\stackrel{\stackrel{్}{్ ల n ~}}{ }$ & 우 & $₹$ & $\underset{N}{N}$ & $\begin{array}{l}L^{\circ} \\
\sigma^{\circ}\end{array}$ & ' \\
\hline ? & $\begin{array}{l}8 \\
10 \\
0 \\
0\end{array}$ & 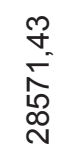 & ల్ల & 우 & $\triangleright$ & $N$ & م & $\stackrel{\mathfrak{L}}{\mathfrak{2}}$ & م & $\stackrel{\llcorner}{\stackrel{L}{\circ}}$ \\
\hline $\begin{array}{l}2 \\
\text { के } \\
\text { के }\end{array}$ & $\begin{array}{l}\text { ¿े } \\
\text { o }\end{array}$ & $\begin{array}{l}\text { m } \\
\stackrel{5}{-} \\
\stackrel{i}{\infty} \\
\stackrel{\infty}{N}\end{array}$ & $\stackrel{\mathbb{N}}{ }$ & $\stackrel{N}{\sim}$ & $\stackrel{\mathscr{\infty}}{\sim}$ & $\nabla$ & 0 & $\stackrel{\infty}{\wedge}$ & $\stackrel{2}{\llcorner}$ & 0 \\
\hline $\begin{array}{l}\overrightarrow{\mathscr{D}} \\
\underline{\underline{T}}\end{array}$ & $\underset{\nabla}{\check{N}}$ & $\begin{array}{l}\hat{\imath} \\
\stackrel{\infty}{\infty} \\
\stackrel{\sim}{F} \\
\stackrel{\sigma}{\sigma}\end{array}$ & $\stackrel{N}{N}$ & $\stackrel{m}{=}$ & $\stackrel{\Re}{\sim}$ & $\nabla$ & ما & $\stackrel{\infty}{\sim}$ & $\sim$ & $\mathscr{L}_{0}^{0}$ \\
\hline $\begin{array}{l}\stackrel{?}{5} \\
\stackrel{0}{0} \\
0\end{array}$ & 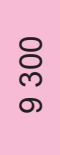 & 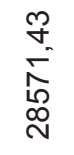 & $\stackrel{\circ}{-}$ & $\stackrel{m}{=}$ & $\stackrel{\circ}{\sim}$ & $\Lambda$ & $F$ & 8 & \& & $F$ \\
\hline$\underset{\frac{p}{\infty}}{>}$ & $\begin{array}{l}8 \\
8 \\
\circ\end{array}$ & 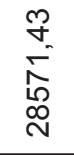 & N & 우 & ธ్ & $m$ & 0 & $\hat{N}$ & 으 & \\
\hline 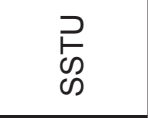 & $\begin{array}{l}\mathscr{D} \\
\infty \\
\circ \\
F\end{array}$ & \begin{tabular}{l}
$\hat{i}$ \\
$\stackrel{\infty}{\sim}$ \\
\multirow{\forall}{}{}
\end{tabular} & $\stackrel{\infty}{N}$ & 우 & ల్ల & 0 & $\stackrel{m}{=}$ & $\widetilde{\varnothing}$ & 尺 & \\
\hline & $\frac{\substack{N \\
F}}{F}$ & 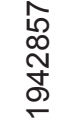 & ' & $F$ & $\stackrel{\mathscr{N}}{\sim}$ & $m$ & $\infty$ & ' & ' & \\
\hline 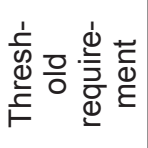 & 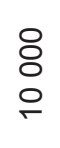 & $\begin{array}{l}\text { m } \\
\stackrel{5}{5} \\
\stackrel{i}{\infty} \\
\stackrel{\infty}{N}\end{array}$ & 尺 & ㅇ & 옴 & $\stackrel{\circ}{\leftarrow}$ & 尺 & & & \\
\hline $\begin{array}{l}\stackrel{x}{\stackrel{\varpi}{0}} \\
\underline{\underline{c}}\end{array}$ & 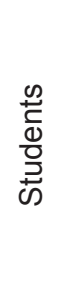 & 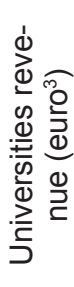 & 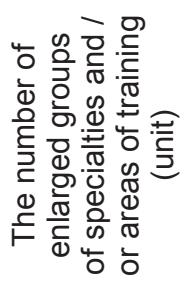 & 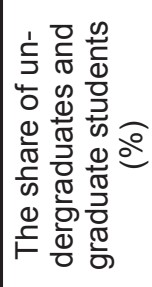 & 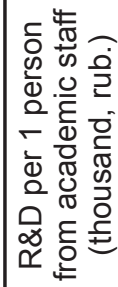 & 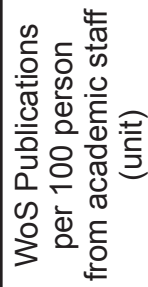 & 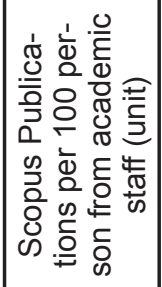 & 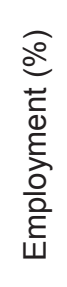 & 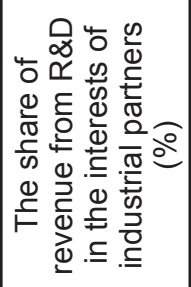 & 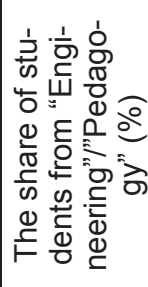 \\
\hline 인 & - & $\sim$ & $m$ & $\nabla$ & ما & 0 & $\wedge$ & $\infty$ & $a$ & 으 \\
\hline
\end{tabular}


Table 7: Existence / deficiency of different ways of cooperation in flagship universities

\begin{tabular}{|c|c|c|c|c|c|}
\hline University & $\begin{array}{c}\text { Small Innovative } \\
\text { Enterprise }\end{array}$ & $\begin{array}{c}\text { Specialized } \\
\text { departments }\end{array}$ & $\begin{array}{c}\text { Technology } \\
\text { incubators }\end{array}$ & Start-ups & R\&D cooperation \\
\hline «IUT» & + & + & + & + & - \\
\hline "KSU» & - & + & + & + & + \\
\hline «SibSAU» & + & + & + & + & + \\
\hline «SPTU» & + & + & + & + & + \\
\hline «VSTU» & + & + & + & + & - \\
\hline «DSTU» & + & + & + & + & - \\
\hline «VISTU» & + & + & + & + & + \\
\hline «SSTU» & + & + & + & + & + \\
\hline «OmSTU» & + & + & + & + & + \\
\hline «OSU» & - & + & + & + & + \\
\hline "VYATSU» & & + & + & + & + \\
\hline
\end{tabular}

\section{REFERENCES}

1. A.I. Sukhinov, E. A. Ugnich SMALL INNOVATIVE ENTERPRISES AT UNIVERSITIES: BARRIERS AND OPPORTUNITIES FOR DEVELOPMENT University management: practice and analysis Vol 21 , № 4, 2017, pp. 98-106, available at: http://umj.ru/ pub/inside/1927/ (accessed 17.12.2017)

2. Average salary in Russia (2016), available at: http:// www.statdata.ru/zpl_rfreg (accessed 09.10.2017)

3. I.V. Arzhanova, A. B. Vorov, D. O. Derman, E. A. Dyachkova, A. V. Klyagin RESULTS OF PILLAR UNIVERSITIES DEVELOPMENT PROGRAM IMPLEMENTATION FOR 2016 University management: practice and analysis Vol 21, № 4, 2017, pp. 11-22 available at: http://umj.ru/pub/inside/1927/ (accessed 15.12.2017)

4. Information-analytical materials ROSSTAT URL: http://www.gks.ru/wps/wcm/connect/rosstat_main/ rosstat/ru/statistics/publications/plan/ (accessed: 20.06.2017)

5. Information-analytical materials ROSSTAT URL: http://www.gks.ru/wps/wcm/connect/rosstat_main/ rosstat/ru/statistics/publications/plan/ (accessed: 20.07.2017)

6. Information-analytical materials ROSSTAT URL: http://www.gks.ru/wps/wcm/connect/rosstat main/rosstat/ru/statistics/publications/catalog/ doc_1138623506156 (accessed: 20.06.2017)

7. Institutional changes in the economics URL: http:// www.gks.ru/wps/wcm/connect/rosstat_main/rosstat/ru/statistics/enterprise/reform/\# 15.06.2017)
8. N.E. Ovchinnikova// Formation of pillar universities as territory development drivers// University management: practice and analysis, Vol 21, №4, 2017, pp. 41- 53 available at: http://umj.ru/pub/inside/1927/ (accessed 23.12.2017)

9. Ranking list of Russian regions for socio-economic situation (2014) URL: http://riarating. ru/infografika/20150616/610658857.html (accessed:05.06.2017)

10. Report on the results of self-analysis Don State Technical University URL: http://www.donstu.ru/upload/documents/ (accessed:18.05.2017)

11. Report on the results of self-analysis Industrial University of Tyumen URL: http://www.tsogu.ru/ wp-content/uploads/2015/05/otchet-o-samoobsledovanii-1-chast-analiticheskij-otchet.pdf (accessed: 20.05.2017)

12. Report on the results of self-analysis Kostroma State Technological University URL: http://www. kstu.edu.ru/univer/docs/Othet_o_samoobsledovanii_21.04.15.pdf (accessed:20.05.2017)

13. Report on the results of self-analysis Omsk State Technical University URL: http://www.omgtu. ru/sveden/document/Othet_o_samoobsledovanii_01.04.2016.pdf (accessed: 22.09.2017)

14. Report on the results of self-analysis Orel State University URL: http://www.univ-orel.ru/files/document/n_eoso.pdf (accessed:18.05.2017)

15. Report on the results of self-analysis Samara State Technical University URL: http://samgtu.ru/university/normativnye-dokumenty (accessed: 22.09.2017)

16. Report on the results of self-analysis Siberian State Aerospace University URL: http://www.sibsau.ru/images/document/2015 (accessed: 18.05.2017) 
17. Report on the results of self-analysis Ufa State Petroleum Technological University URL: http://www. rusoil.net/pages/2184/2014(accessed: 21.05 .2017 )

18. Report on the results of self-analysis Volgograd State Technical University URL: http://www.vstu.ru/ files/webmaster/2015-03/9681/upload/18.04.2016_ otchet_o_samoob_volggtu_annot_vers_itog.pdf (accessed: 07.09.2017)

19. Report on the results of self-analysis Voronezh State Technical University URL: http://www.vorstu.ru/upravlenie/rdoc (accessed: 18.05.2017)

20. Report on the results of self-analysis Vyatka State University URL: https://www.vyatsu.ru/uploads/ file/1504/2014_otchet_o_samoobsledovanii_po_ vuzu_polnyy.pdf (accessed: 19.05.2017)

21. Russian Federation Federal State Statistics Service, available at: http://www.gks.ru/wps/wcm/connect/ rosstat_main/rosstat/ru/statistics/publications/catalog/doc_1138623506156 (accessed 07.08.2017)

22. Russian regions ranking for quality of life, available at: http://riarating.ru/regions/20170220/630056195. html (accessed 10.12.2017)

23. Russians regions. The main characteristics of the Russian Federation regions URL: http://www.gks. $\mathrm{ru} / \mathrm{wps} / \mathrm{wcm} /$ connect/rosstat_main/rosstat/ru/statistics/publications/catalog/doc_1138625359016 (accessed: 29.08.2017)
24. The number of Russian population by municipalities URL: http://www.gks.ru/wps/wcm/connect/rosstat main/rosstat/ru/statistics/publications/catalog/ (accessed: 21.06.2017)

25. The ranking list of the Russian regions on quality of living http://riarating.ru/regions/20170220/630056195. html (accessed: 21.10.2017)

26. The ranking list of the Russian regions on the socio-economic situation http://vid1.rian.ru/ig/ratings/ rating_regions_2016.pdf (accessed: 21.09.2017)

27. The Russia economy http://www.europarl.europa. eu/RegData/etudes/IDAN/2015/551320/EPRS IDA\%282015\%29551320_EN.pdf (accessed: $01.12 .2017)$

28. The Russiaeconomy, availableat:http://www.europarl. europa.eu/RegData/etudes/IDAN/2015/551320/ EPRS_IDA\%282015\%29551320_EN.pdf (accessed 23.11.2017)

29. 29. The socio-economic ranking situation of the Russian Federation subjects, available at: http:// vid1.rian.ru/ig/ratings/rating_regions_2016.pdf (accessed 03.06.2017) 